\title{
DETERMINANTS OF CAPITAL STRUCTURE: EVIDENCE FROM INDONESIAN PALM OIL COMPANIES
}

\author{
Cynthia Sari DEWI \\ Faculty of Business, Universitas Multimedia Nusantara, Tangerang, Indonesia \\ cynthia.sari@umn.ac.id \\ Brighton JORDY \\ Faculty of Business, Universitas Multimedia Nusantara, Tangerang, Indonesia \\ brighton.jordy@student.umn.ac.id \\ Harris WIJAYA \\ Faculty of Business, Universitas Multimedia Nusantara, Tangerang, Indonesia \\ harris.wijaya@student.umn.ac.id
}

\begin{abstract}
This study to find out the determinants of capital structure in the palm oil industry in Indonesia. The variables are commodity prices, total assets, tangible assets, profitability, asset turnover, liquidity, inventory turnover, interest rates, and capital structure as independent variables. The data processing uses SPSS version 25 and performs classical assumption test, coefficient of determination test, and multiple regression analysis. The object of this study is oil palm plantation companies listed in Indonesian stock exchange (IDX) period 2016 to 2019. The results show that CPO prices, total assets, tangible assets, profitability, and interest rates have no effect on capital structure. Meanwhile, asset turnover has a positive effect on capital structure. Current ratio has a negative effect on the capital structure. Inventory turnover has a negative effect on the capital structure of oil palm plantation companies. This research is useful for companies engaged in the palm oil industry in determining policies.

Keywords: Capital Structure, Crude Palm Oil, Asset Turnover, Current Ratio, Inventory Turnover DOI: https://doi.org/10.24818/beman/2021.11.4-04
\end{abstract}

\section{INTRODUCTION}

During this era, especially science and technology continues to encourage progress in many sectors of life through various breakthroughs. One of the things that has become a global concern and directly encourages many countries to innovate to protect the environment is to look for substitutes of petroleum. In 2017, the Indonesian government began to launch a program that mixes diesel with crude palm oil (CPO) and it has been realized and has been applied since September 1, 2018 according to Lembaga 
Penyelidikan Ekonomi dan Masyarakat (2020). The biodiesel project will be carried out in stages, with the following details:

TABLE 1. BIODIESEL PROJECT COMPOSITION AND DEVELOPMENT

\begin{tabular}{|l|l|l|l|l|}
\hline No. & Description & Code & Composition & Applied Since / Will Apply in \\
\hline 1 & Biodiesel 20/Diesel Fuel 20 & B20 & $80 \%$ Diesel Fuel and 20\% CPO & 1 September 2018 \\
\hline 2 & Biodiesel 30/Diesel Fuel 30 & B30 & $70 \%$ Diesel Fuel and 30\% CPO & Beginning of 2020 \\
\hline 3 & Biodiesel 40/Diesel Fuel 40 & B40 & $60 \%$ Diesel Fuel and 40\% CPO & Middle of 2021 \\
\hline 4 & Biodiesel 50/Diesel Fuel 50 & B50 & $50 \%$ Diesel Fuel and 50\% CPO & 2022 \\
\hline 5 & Biodiesel 100 & B100 & $100 \%$ CPO & Estimated in 2025 \\
\hline
\end{tabular}

Source: LPEM FEB UI (2020)

If viewed from an economic perspective, the plantation sector contributes $1.8 \%$ to Indonesia's GDP in 2020 , with oil palm plantations dominating with a total production of $29,637.5$ tons or equivalent to $83.3 \%$ of the total production of the plantation industry (Databoks, 2021). The implementation of the government's B30 project has resulted in domestic palm oil absorption, increasing by $23.5 \%$ in 2020 compared to the previous year, increasing from 5.8 million tons to 7.2 million tons. Also, by observing the government's plan which will implement up to B100, of course palm oil companies need to increase their production to meet the demand for palm oil for the project, at the same time companies need to meet the increasing demand for palm oil absorption for the oleochemical industry (soap, detergent, hand sanitizer). The implementation of government policies encourages palm oil companies on the production side to meet consumer demand. If management is too centered on consumer demand, it can cause agency problems in which managers take policies that are detrimental to shareholders. While the main goal of financial managers is to increase the value of the company. Firm value can also be defined by market value (Ross et al., 2012). 


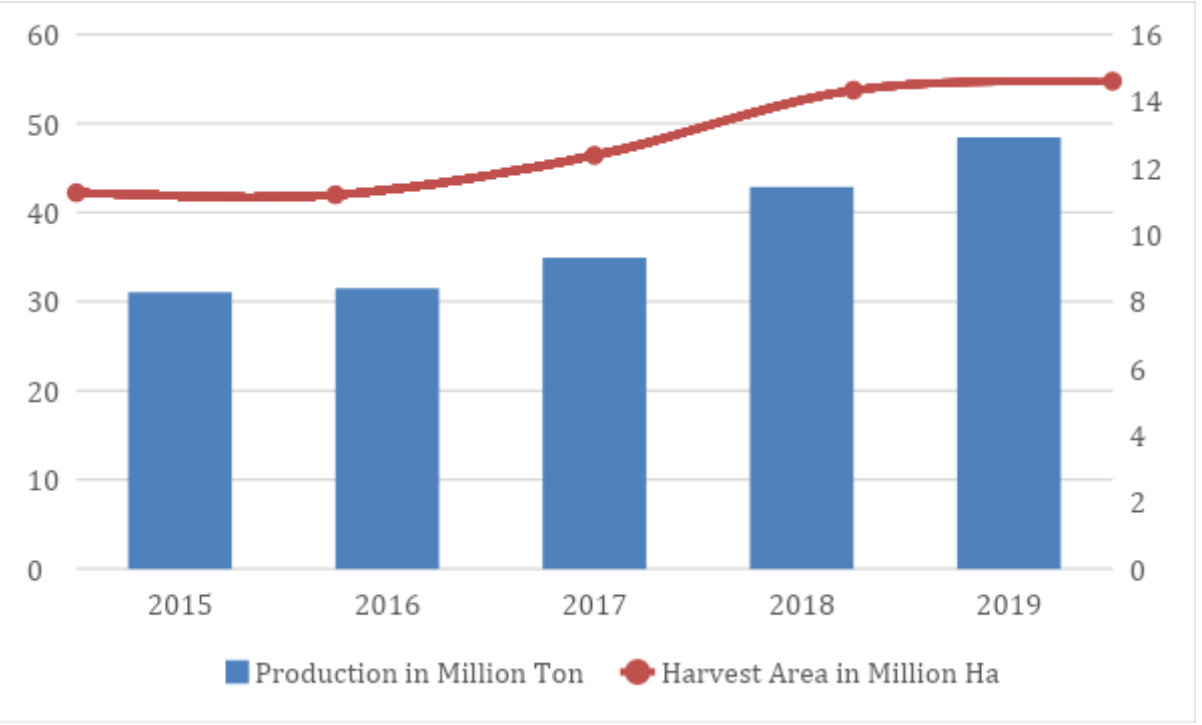

FIGURE 1. PRODUCTION AND HARVEST AREA OF PALM OIL PLANTATION

Source: BPS Publication, 2019

Indonesia itself is the largest palm oil producer in the world with an expected production of 44.5 million tons of palm oil-based on indexmundi data, followed by Malaysia with an expected production of 19.7 million tons of palm oil. Indonesia's palm oil plantation industry has been on the rise for the last 5 years. It is seen in the data taken from BPS Huge rise of production and harvest area according to data taken from BPS, there has been a rise in production and harvest area in the span of 5 years. If we look closely at the data, since the government has launched a mixed diesel and crude palm oil plan in 2017 there has been a huge rise in production in 2018 and 2019 compared to the previous 3 years. Considering only B20 is implemented at that time, it shows a huge potential for the palm oil plantation if the palm oil can be implemented $100 \%$ as a substitute for petroleum.

But on the other hand, if the company fails to balance the capital structure from obtaining external funding sources to meet needs or opportunities in the market with risks from external funding sources, the consequences can be fatal. For example, what happened to PT. Sariwangi Agricultural Estate Agency (SAEA) and PT Airline Plantation Indorub Sumber Wadung (MPISW) went bankrupt in 2018 due to not being able to pay off their bank debts (Merdeka, 2018). PT. Sariwangi Agricultural Estate Agency (SAEA) and PT Airline Plantation Indorub Sumber Wadung (MPISW) invested in their assets to increase the company's productivity by using external funding which resulted in changes in the capital structure being dominated by debt. But it turns out that the investments made did not go as desired and did not generate the expected income. As a result, the company does not have sufficient cash income to pay its borrowed debts and the company is forced to go bankrupt and liquidated to pay its debts. 
CPO price is one of the determining income factors that affected the industry significantly. The increase in the market price of CPO will affect the company's income, the higher the market price of CPO the higher income obtained by the company because the commodity can be sold at a higher price. But in general, commodity prices including CPO have high volatility which is very dependent on the demand and supply in the market, the more supply, the commodity prices will decrease and vice versa. In addition, macroeconomic factors also play a role in the movement of CPO commodity prices such as the amount of tax imposed or the instability that occurs in the global economy.

Capital structure refers to where the company gets its resources from. Debt to Equity Ratio (DER) is a measure of total short-term and long-term debt compared to the total capital owned by a company. Low Debt to Equity Ratio (DER) indicates that the smaller the capital structure funded by debt. Conversely, the higher the Debt to Equity Ratio (DER) value, the higher the risk of default for the company because of the large debt owned by the company. The Pecking Order Theory states that companies prefer to use retained earnings as a source of funding because of low risk, and if the company's internal funding sources do not meet the needs, the company will use external funding so as not to lose investment opportunities or as a last resort so that the company can survive according to Myers (1984). Therefore, it is necessary to find optimal balance in which the company can provide shareholders with benefits by considering the risk of default and bankruptcy in accordance with the Balance Theory. This theory requires companies to find a midpoint between positive benefits and possible losses.

\section{LITERATURE REVIEW}

\section{Capital Structure Theory}

Capital structure is the amount of debt and/or equity used by the company to finance operational activities and purchase company assets. The previous statement contradicts the theory of capital structure which was first proposed by Modligani \& Miller (1958) and define that in a perfect capital market without frictions, bankruptcy costs and information asymmetry, the theory is that the company's value is independent of how the company finances operational and investment activities so that irrelevant to the company's capital structure Neves et al (2020). This theory, which is quite controversial, has caused many other theories to emerge, most of which are carried out to find out or clarify the company's financial decisions in conducting funding based on its capital structure.

The trade-off theory was introduced by Kraus \& Litzenberger (1973), stating that the trade-off theory is a tax-based theory and argues that an optimal and balanced capital structure can maximize shareholder welfare, along with increasing firm value and minimizing risk. According to a study conducted by Degreyse 
\& Kappert (2012) an optimal capital structure can be used as a trade-off between benefits and costs for debt financing.

Pecking-order theory developed by Myers (1984) which assumes that a company's financial decisions are made by following a certain hierarchical order in selecting funding sources to minimize information mismatches. Quoting from Neves et al (2020), this theory suggests that companies prefer retained earnings with low risk, but when internal funds are insufficient or weakened, companies tend to switch to low-risk debt to still have the opportunity to maintain investment. This theory also states that a company will issue new shares as a last resort if that company is unable to obtain loans to assist funding activities. Agency costs theory proposed by Jensen \& Meckling (1976) which broadly explains how conflicts between managers and company owners, or conflicts between managers/owners and creditors can affect the company's financial decisions due to differences in goals and opinions experienced.

Market timing theory developed by Lucas \& McDonald (1990)] that is based on capital market imperfections. This theory assumes that when a company makes a decision, it always considers the time and market value of the stock. Therefore, companies prefer to issue shares when their shares are overvalued and buy back when shares are undervalued, so Baker \& Wurgler (2007) conclude that the company's capital structure is the result of the company's various experimental actions from its capital market activities.

\section{Hypothesis Development}

According to Kurronen (2018), the trade-off theory argues that companies must find a balance between equity and debt to maximize firm value, which supports his opinion that the company's lending and borrowing activities when commodity prices rise will affect the company's capital structure by Herrusugondo et al. (2015), Putra \& Robiyanto (2019), and Sutomo et al (2019), when commodity prices are high, companies will boost sales with the aim of maximizing the value of the company by using internal and external resources so as to encourage companies to apply for loans due to financial pressures that occur. Research conducted by Utomo et al (2018) \& Nnadi (2016) shows that the size of the company has a positive influence on the capital structure.

Fixed assets are usually obtained through debt and are considered as a support for creditors as a form of company liquidation Alipour et al (2015). That statement is supported by many theories related to capital structure which argue that the type of assets owned by the company in particular can affect the company's capital structure Acaravci (2015). Quoting from Neves et al (2020), there are many debates about the relationship between company profitability and capital structure, but from several previous studies conducted by Akinyomi \& Olagunju (2013) \& Serrasqueiro et al. (2016). 
Serrasqueiro et al. (2016) \& Vo (2017) supports the pecking order theory which states that profitable companies will be able to fund their investments with internal funds and not rely on external funding so they will be less likely to go bankrupt. According to Asteriou et al. (2007), inventory turnover influences the company's capital structure because if the inventory turnover is low, then the company's capital structure decreases because it describes the company's management that has not been effective in managing inventory because goods have accumulated (weak turnover).

Smaller asset turnover indicates a decrease in the company's asset turnover activity which causes the company to use debt to cover the company's cash flow (Yusnandar, 2019), (Weestgard et. al., 2008) \& (Wardhana \& Mawardi, 2016) it can be expected that there will be a negative effect between asset turnover and capital structure. Ahuja \& Kalra (2020) also found that more debt was raised by companies when interest rates were low when compared to previous interest rates.

According to previous study it is known that only a firm age doesn't have any significant impacts on the capital structure and tangibility, liquidity, and profitability have an impact on the capital structure (Chandra et. al., 2020). Meanwhile Chakrabati \& Chakrabati (2018) found that profitability, debt service capacity, sales growth, non-debt tax shield and tangibility ratio to be insignificant determinants. Studies conducted by Lussuamo \& Serrasqueiro (2021) stated that tangibility is a determining factor in the decisions of the capital structure of SMEs in the province of Cabinda, Angola.

$\mathrm{H}_{1}$ : There is a relationship between Commodity prices and capital structure.

$\mathrm{H}_{2}$ : There is a relationship between Total Assets and capital structure.

$\mathrm{H}_{3}$ : There is a relationship between Tangible assets and capital structure.

$\mathrm{H}_{4}$ : There is a relationship between Profitability and capital structure.

$\mathrm{H}_{5}$ : There is a relationship between Asset turnover and capital structure.

$\mathrm{H}_{6}$ : There is a relationship between Liquidity and capital structure.

$\mathrm{H}_{7}$ : There is a relationship between Inventory turnover and capital structure.

$\mathrm{H}_{8}$ : There is a relationship between Interest rate and capital structure. 


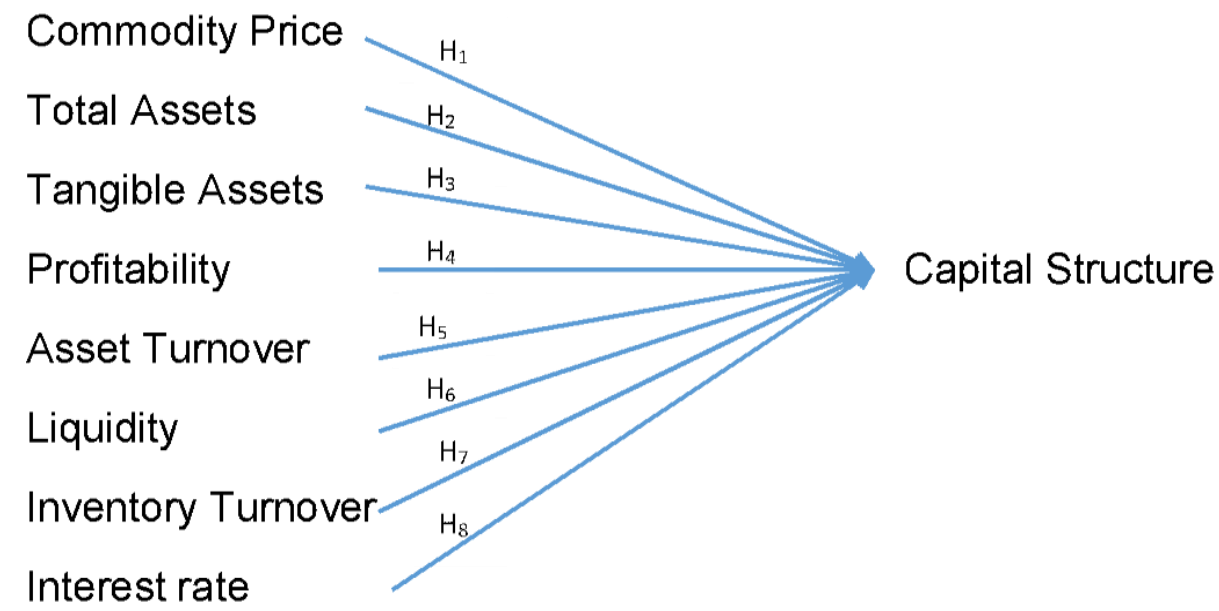

FIGURE 2. RESEARCH FRAMEWORK

Source: Framework Authors

\section{RESEARCH METHODS}

This study uses secondary data in the form of quantitative, namely in the form of financial statement data that has been processed from the companies that are the samples of this study as well as commodity price and interest rate data. Variables that are used in this research are commodity prices, assets, profitability, liquidity, interest rates, on capital structure. The data that we used is non-probability purposive sampling data which is palm oil plantation company with a market cap of over 1 trillion rupiahs to filter out inappropriate data. Thus, resulting the sample as follows:

TABLE 2. LIST OF SAMPLE: PAM OIL PLANTATION COMPANY

\begin{tabular}{|c|c|c|}
\hline No & Company & Market Cap In Trillion Rupiah \\
\hline 1 & AALI & 19.20 \\
\hline 2 & SMAR & 11.12 \\
\hline 3 & SSMS & 8.91 \\
\hline 4 & LSIP & 8.70 \\
\hline 5 & SIMP & 7.84 \\
\hline 6 & DSNG & 6.47 \\
\hline 7 & TBLA & 4.73 \\
\hline 8 & SGRO & 3.31 \\
\hline 9 & ANJT & 2.26 \\
\hline \multicolumn{2}{|c|}{ Source: Indonesian Stock Exchange (2021) }
\end{tabular}


The data collection method that the researcher uses is by downloading files from the Indonesia Stock Exchange website starting in 2016 - 2019 and for the Jibor rate researcher access through the Bank Indonesia website, and for palm oil commodity prices we use the Medan spot rate from the CoFTRA website. In addition, other supporting instruments such as previous similar studies, research data and journals to support this research. The software used in this study is SPSS version 25. The software used in this study is SPSS version 25. The indicator of operational variable is described in the table below:

TABLE 3. TABLE OF OPERATIONAL VARIABLE

\begin{tabular}{|c|c|c|c|}
\hline Variable & Definition & Measurement & Ref \\
\hline $\begin{array}{l}\text { Capital } \\
\text { Structure }\end{array}$ & The proportion of debt versus equity & $\begin{array}{l}\mathrm{DER}=(\text { Total } \\
\text { Debt }) /(\text { Total } \\
\text { Equity })\end{array}$ & Neves et al (2020) \\
\hline $\begin{array}{l}\text { Commodity } \\
\text { Price }\end{array}$ & $\begin{array}{l}\text { The price of basic goods used in trade that } \\
\text { can be exchanged for other similar goods }\end{array}$ & $\begin{array}{l}\text { Crude Palm Oil } \\
\text { Price }\end{array}$ & $\begin{array}{l}\text { Kurronen (2018), } \\
\text { Herrrusugondo (2015), \& } \\
\text { Sutomo et al (2019) }\end{array}$ \\
\hline Size & All assets owned by the company & Total Asset & $\begin{array}{l}\text { Sutomo et al; (2019), } \\
\text { Utomo et al (2018), \& } \\
\text { Nnadi (2016) }\end{array}$ \\
\hline $\begin{array}{c}\text { Asset } \\
\text { Tangibility }\end{array}$ & $\begin{array}{l}\text { Assets that have limited monetary value, } \\
\text { have a physical form and transactional }\end{array}$ & $\begin{array}{l}\text { Asset Tangibility } \\
=\text { (Intangible } \\
\text { asset)/(Total } \\
\text { Asset) }\end{array}$ & $\begin{array}{c}\text { Sutomo et al } \\
\text { (2019),Alipour et al } \\
\text { (2015), \& Acaravci } \\
\text { (2015) }\end{array}$ \\
\hline $\begin{array}{l}\text { Profitability } \\
\text { (ROA) }\end{array}$ & $\begin{array}{l}\text { Primary goal for the company to survive in } \\
\text { the long run. }\end{array}$ & $\begin{array}{c}\mathrm{ROA}=(\text { Net } \\
\text { income }) /(\text { Total } \\
\text { Asset })\end{array}$ & $\begin{array}{l}\text { Sutomo et al (2019) \& } \\
\text { Serrasqueiro et al (2016] }\end{array}$ \\
\hline $\begin{array}{l}\text { Asset } \\
\text { Turnover }\end{array}$ & $\begin{array}{c}\text { Asset frequency to see how efficiently the } \\
\text { company uses assets in a year to generate } \\
\text { company revenues }\end{array}$ & $\begin{array}{l}\text { Asset Turnover } \\
\quad=(\text { Net } \\
\text { sales }) /(\text { Total } \\
\text { Asset })\end{array}$ & Yusnandar (2019) \\
\hline $\begin{array}{l}\text { Current } \\
\text { Ratio }\end{array}$ & $\begin{array}{l}\text { The company's ability to pay short-term } \\
\text { debt using the company current asset }\end{array}$ & $\begin{array}{l}\text { Current Ratio = } \\
\text { (Current Asset)/( } \\
\text { Short-term debt) }\end{array}$ & $\begin{array}{l}\text { Sutomo et al (2019), } \\
\text { Serrasqueiro et al } \\
\text { (2016), \& Vo (2017) }\end{array}$ \\
\hline
\end{tabular}




\begin{tabular}{|c|c|c|c|}
\hline $\begin{array}{c}\text { Inventory } \\
\text { Turnover }\end{array}$ & $\begin{array}{c}\text { Inventory frequency to see how efficiently } \\
\text { the company manages inventories } \\
\text { compared to the goods sold uses assets in } \\
\text { a year to generate company revenues }\end{array}$ & $\begin{array}{c}\text { Inventory } \\
\text { Turnover }= \\
\text { COGS/(Total } \\
\text { Inventory) }\end{array}$ & Asteriou et al (2007) \\
\hline Interest Rate & $\begin{array}{c}\text { Rates of returns for receivers or rates of risk } \\
\text { for issuers }\end{array}$ & $\begin{array}{c}\text { JIBOR Interest } \\
\text { Rate }\end{array}$ & $\begin{array}{c}\text { Sutomo et al (2019) \& } \\
\text { Nnadi (2016) }\end{array}$ \\
\hline
\end{tabular}

Source: The Authors

\section{FINDINGS AND RESULTS}

The object of this research is calm oil plantation companies listed in Indonesian Stock Exchange (IDX) from 2016 to 2019 and dependent variable is Capital structure with total observations of 36 data. Classical assumption test is a requirement that must be met in multiple regression analysis. This study has passed the normality test, heteroscedasticity test, autocorrelation test and multicollinearity test with further explanation in table 4 (Ghozali, 2016).

TABLE 4. SUMMARY CLASSICAL ASSUMPTION TEST

\begin{tabular}{|l|l|l|}
\hline $\begin{array}{l}\text { Classical assumption } \\
\text { test }\end{array}$ & Requirements & Description of test results \\
\hline Normality Test & Sig. KS-Test $>0.05$ & $\begin{array}{l}\text { Pass the test (Unstandardized Residual } \\
\text { results Sig. }>0.05)\end{array}$ \\
\hline Heteroscedasticity Test & $\begin{array}{l}\text { Scatterplots } \\
\text { scattered points }\end{array}$ & $\begin{array}{l}\text { Pass the test (scatterplots show scattered } \\
\text { points) }\end{array}$ \\
\hline Autocorrelation test & $\begin{array}{l}\mathrm{dl}<\mathrm{d}<\mathrm{du} \\
\text { table } \llbracket \mathrm{dl} 0,9913 ; \mathrm{du} 2,0410\end{array}$ & $\begin{array}{l}\text { Pass the test }(\mathrm{d}=1,246) \\
0.9913 \leq 1.246 \leq 2.0410\end{array}$ \\
\hline Multicollinearity Test & $\begin{array}{l}\text { Tolerance }>0,1 \\
\text { VIF }<10\end{array}$ & $\begin{array}{l}\text { Pass the test (Tolerance and VIF in } \\
\text { accordance) }\end{array}$ \\
\hline
\end{tabular}

Source: Ghozali (2016), Results from SPSS 25.0, 2021

The coefficient of determination serves to determine the magnitude of the influence of the independent variable on the dependent variable which is manifested in the form of a percentage. Research is considered better if it has a high adjusted $R$ square value.

TABLE 5. MODEL SUMMARY DAN ANOVA 


\begin{tabular}{|c|c|c|c|c|c|c|}
\hline Model & $\mathrm{R}$ & R square & Adj. R square & Std error & F-test & Sig. \\
\hline 1 & 0.831 & 0.691 & 0.6 & 0.46442 & 7.556 & 0.000 \\
\hline
\end{tabular}

Predictors: (Constant), Interest rate, Total Asset, ROA, Current Ratio, Inventory turnover, CPO Price, Asset turnover, Asset Tangible

Dependent Variable: DER

Source: SPSS 25.0, 2021

Based on table 5 , it can be seen that the adjusted $R$ square value is 0.6 . Based on the simultaneous significance test, it can be seen that the significance obtained is 0.000 , or lower than the critical value (0.05). So, statistically, it can be concluded that HO9 is rejected, so that commodity prices, total assets, tangible assets, profitability, asset turnover, liquidity, inventory turnover and interest rates simultaneously affect the capital structure.

Hypothesis testing is carried out using multiple regression analysis which aims to test how the partial effect of the independent variable on the dependent variable is by comparing t-count and t-table. If t-count is greater than t-table, then $\mathrm{H} 0$ is rejected, and if t-count is smaller than t-table, then $\mathrm{HO}$ is not rejected.

TABLE 6. MULTIPLE REGRESSION RESULTS (T-TEST)

\begin{tabular}{|l|r|l|l|}
\hline & B & t & sig \\
\hline (Constant) & 4.057 & 3.439 & $\mathbf{0 . 0 0 2 ^ { * }}$ \\
\hline CPO Price & -37.029 & -0.814 & 0.423 \\
\hline Total Asset & -0.023 & -1.038 & 0.308 \\
\hline Tangible asset & -0.03 & -1.296 & 0.206 \\
\hline ROA & -3.092 & -1.165 & 0.254 \\
\hline Asset Turnover & 0.987 & 2.765 & $\mathbf{0 . 0 1 ^ { * }}$ \\
\hline Current Ratio & -0.175 & -2.771 & $\mathbf{0 . 0 1 ^ { * }}$ \\
\hline Inventory Turnover & -0.229 & -5.56 & $\mathbf{0 . 0 0 *}$ \\
\hline Interest Rate & -10.266 & -0.975 & 0.338 \\
\hline \multicolumn{4}{|c|}{ Source: SPSS 25.0, 2021 } \\
\hline
\end{tabular}

According to the tables above, the regression equation can be arranged as follows:

$Y=4,057-37,029 X_{1}-0,023 X_{2}-0,03 X_{3}-3,092 X_{4}+0,987 X_{5}-0,175 X_{6}-0,229 X_{7}-10,266 X_{8}$ 


\section{DISCUSSION}

Through the regression equation, it is known that the intercept value is 4.057 , which means that when all independent variables are 0 , then the capital structure/DER is 4.057 . CPO price has no effect on the capital structure. This is due to the significance value of CPO Price which is greater than 0.05 , which is 0.423 , so that $\mathrm{HO}$ is not rejected. Therefore, the price of CPO commodities has no effect on the capital structure. These results are consistent with research results Sutomo et al (2019). Total assets have no effect on the capital structure. This happens because the value of the significance of total assets is greater than 0.05 , which is 0.308 , so that $\mathrm{H} 0$ is not rejected. Therefore, the company's total assets have no effect on the capital structure. These results are in accordance with the results of the study [15]. Moreover, these results do not support the proprietary trade-off theory Kraus \& Litzenberger (1973). Tangible assets have no effect on the capital structure. This happens because the significance value of tangible assets is greater than 0.05 , which is 0.206 , so $\mathrm{H} 0$ is not rejected. Therefore, tangible assets have no effect on the capital structure. These results do not support studies Acaravci (2015), Akinyomi \& Olagunju (2013), Chandra et al (2020), Haron et al (2021), \& Shahzad et al (2020). ROA has no effect on the capital structure. This is because the significance value of ROA is greater than 0.05 , which is 0.254 , so HO is not rejected. Therefore, ROA has no effect on the capital structure. These results do not support studies Akinyomi \& Olagunju (2013), Serrasqueiro et al (2016) , \& Chandra et al (2020).

Asset turnover has a positive effect on the capital structure. This happens because the significant asset turnover value is smaller than 0.05 , which is 0.01 , so $\mathrm{H} 0$ is rejected. Therefore, asset turnover has a positive effect on the capital structure. These results do not support studies Yusnandar (2019), Weestgaard et al (2016), \& Wardhana \& Mawardi (2016). But this result is supported by study Chakrabati \& Chakrabati (2018). The managerial implication of this result is that company's management is advised to pay attention to the asset turnover ratio. High asset turnover indicates the company's efficiency in using assets to generate good sales. If the company has a good asset turnover, this makes the company's growth potential even bigger, and to maximize this potential the company can increase its leverage so that its business scale grows and gets higher profits.

Current ratio has a negative effect on the capital structure. This happens because the value of the significance current ratio is smaller than 0.05 , which is 0.01 , so that $\mathrm{HO}$ is rejected. Therefore, the current ratio has a negative effect on the capital structure. This result is not in accordance with the studies of Serrasqueiro et al (2016), Chandra et al (2020), Chakrabati \& Chakrabati (2018), Lussuamo \& Serrasquiero (2021),\& Shahzad et al(2020) . The managerial implication of this result is, when the company has a high liquidity ratio, in this case the current ratio, it means that the company does not need to add debt, because all of the company's current liabilities can be financed by current assets. Also to 
expand their business growth, companies can lower their current ratio by adding current debt to its balance sheet. However, it must take the point that a lower current ratio can increase the risk of default on debt.

Inventory turnover has a negative effect on the capital structure. This is because the value of the significance of inventory turnover is smaller than 0.05 , which is 0.00 , so $\mathrm{HO}$ is rejected. Therefore, inventory turnover has a negative effect on the capital structure. These results are consistent with research Asteriou et al (2007). The managerial implication of this result is that companies must carry out inventory management well. If a company has a high inventory turnover ratio, then the company's cash flow is smooth, so it does not need financing from outside sources, and means that the company does not need to incur excessive interest expenses. Thus, the company can consider expanding its business using internal funding or even external funding if needed. The reason is good cash flow lowered the risk of default. In other words, the company can take external funding to take advantage of the existing opportunities.

Interest rate has no effect on the capital structure. This happens because the value of the significance interest rate is greater than 0.05 , which is 0.338 , so that $\mathrm{HO}$ is not rejected. Therefore, the interest rate has no effect on the capital structure. These results do not support the study Ahuja \& Kalra (2020).

\section{CONCLUSION}

Based on the results of the study, the CPO price, total assets, tangible assets, profitability, and interest rate have no effect on the capital structure. Meanwhile, asset turnover has a positive effect on the capital structure. Current ratio has a negative effect on the capital structure. Inventory turnover has a negative effect on the capital structure of oil palm plantation companies.

This study uses oil palm plantation companies listed on IDX in 2016-2019. So that further researchers are advised to use a longer period of observation to capture the entire boom and bust cycle of the CPO industry, so as to produce more accurate results. In addition, taking other sectors as observations, especially industries engaged in the commodity sector. That way, researchers will get differences in capital structure conditions between commodity industries.

\section{REFERENCES}

Acaravci, S. K. (2015). The Determinants of Capital Structure: Evidence from the Turkish Manufacturing Sector. International Journal of Economics and Financial Issues, 158-171. 
Ahuja, B. R., \& Kalra, R. (2020). Impact of Macroeconomic Variables on Corporate Capital Structure: A Case of India.

Akinyomi, O. J., \& Olagunju, A. (2013). Determinants of Capital Structure in Nigeria. International Journal of Innovation and Applied Studies, 999-1005.

Alipour, M., Mohammadi, M. F., \& Derakhshan, H. (2015). Determinants of Capital Structure: An Empirical Study of Firms in Iran. International Journal of Law and Management, 53-83.

Baker, M. \& Wurgler, J. 2007. Investor Sentiment in the stock market. Journal of Economic Perspectives, 21(2): 129-152.

BPS Publication.2019. Statistik Kelapa Sawit Indonesia.

Chakrabati, A. \& Chakrabati, A. (2018). The capital structure puzzle - evidence from Indian energy sector. International Journal of Energy Sector Management, 13(1): 2-23, 10.1108/IJESM-03-2018-0001.

Chandra, T., Chandra, S., Wijaya, E., Chandra, J., Ng, M. (2020). Co-determination of capital structure and profitability: An empirical test of Indonesia stock exchange. Industrial Engineering and Management Systems, 19(3): 561-575, 10.7232/iems.2020.19.3.561.

Ghozali, I. (2016). Aplikasi Analisis Multivariate Dengan Program IBM SPSS 23", (Edisi 8). Cetakan ke VIII. Semarang : Badan Penerbit Universitas Diponegoro.

Haron, R. Nomran, N.M., Abdullah, O.AH, Md-Husin, M. \& Sharofiddin, A. (2021).The influence of firm, industry and concentrated ownership on dynamic capital structure decision in emerging market. Journal of Asia Business Studies, 15 (5): 689-709.

Jensen, M. C. \& Meckling, W. H. (1976). Theory of the firm: Managerial Behaviour, Agency Cost and Ownership structure. Journal of Financial Economics, 3: 305-360.

Kraus, A. \& Litzenberger, R.H. (1973). A state-preference Model of Optimal Financial Leverage. The Journal of finance, 28 (4): 911-922.

Kurronen, S. (2018). Natural Resources and Capital Structure. Economic Systems.

Lembaga Penyelidikan Ekonomi dan Masyarakat. (2020). Risiko Kebijakan Biodiesel dari sudut pandang Indikator Makro dan Lingkungan. Fakultas Ekonomi dan Bisnis, Universitas Indonesia,Greenpeace.org.

Lucas, D. J. \& McDonald, R. L. (1990). Equity Issues and Stock price dynamics. The Journal of finance, 45(4): 1019-1043.

Lussuamo, J. \& Serrasqueiro, Z. (2021).What are the determining factors in the capital structure decisions of small and medium-sized firms in Cabinda, Angola?. Revista Contabilidade e Financas, 32(87): 476-491.

Merdeka.com,.(2018).PT Sariwangi diputus pailit, Unilever pastikan produk SariWangi tetap diproduksi.,https://www.merdeka.com/uang/pt-sariwangi-diputus-pailit-unilever-pastikan-produksariwangi-tetap-diproduksi.html.

Modligani, F. \& Miller, M.H.(1958).The cost of capital, corporation finance and the theory of investment. The American Economic Review, 48 (3): 261-297.

Myers, S. C.(1984).The Capital Structure Puzzle. The Journal of Finance, 39(3): 574-592.

Neves, M. E., Serrasqueiro, Z., Dias, A., \& Hermano, C. (2020).Capital Structure Decisions in A Period of Economic Intervention: Empirical Evidence of Portuguese Companies with Panel Data. International Journal of Accounting and Information Management.

Nnadi, M. (2016). Accounting Factors Affecting the Capital Structure in the Asian Economic Community. International Journal of Accounting Research, 5(1): 1-9. 
Putra, A. R., \& Robiyanto. (2019). The Effect of Commodity Price Changes and USD/IDR Exchange Rate on Indonesian Mining Companies' Stock Return. Jurnal Keuangan dan Perbankan, 97-108.

Ross, S., Westerfield, R. W., Jordan, B. D., Joseph, L. \& Tan, R. (2012). Fundamental of Corporate Finance'. Asia Global Edition, McGrawHIl: Asia.

Serrasqueiro, Z., Matias, F., \& Salsa, L. (2016). Determinants of Capital Structure: New Evidence from Portuguese Small Firms. Dos Algarves: A Multidisciplinary e-Journal, 13-28.

Shahzad, A., Azeem, M., Nazir, M.S., Vo, X.V., Linh, N.T.M. (2020). The determinants of capital structure: Evidence from SAARC countries. International Journal of Finance and Economics, 26(4): 64716487.

Sutomo, Wahyudi, S., Pangestuti, I. R., \& Muharam, H. (2019). The Determinants of Capital Structure in Coal Mining Industry on the Indonesia Stock Exchange. Investment Management and Financial Innovations.

Utomo, M. N., Wahyudi, S., Muharam, H., \& Taolin, M. L. (2018). Strategy to improve firm performance through operational efficiency commitment to environmental friendlines: Evidence from Indonesia. Organizations and Markets in Emerging Economies, 9(1): 62- 85.

Vo, X. V. (2017). Determinants of Capital Structure in Emerging Markets: Evidence from Vietnam. Research in International Business and Finance.

Wardhana, I. B., \& Mawardi, W. (2016). Analisis Pengaruh Struktur Aktiva, Asset Turnover, Growth terhadap Profitability melalui Variabel Capital Structure sebagai Variabel Intervening (Studi Kasus pada Perusahaan Consumer Goods BEI Tahun 2012-2014). Diponegoro Journal of Management, $1-14$.

Yusnandar, W. (2019). Pengaruh Current Ratio, Return on Asset, Asset Structure dan Total Asset Turnover terhadap Debt to Equity Ratio pada Perusahaan Perkebunan yang Terdaftar di Bursa Efek Indonesia. Jurnal KRISNA: Kumpulan Riset Akuntansi, 71-80. 